\title{
The Relation of Pantothenic Acid to Acetylcholine Forma- tion by a Strain of Lactobacillus plantarum
}

\author{
By ELIZABETH ROWA'TT \\ Departments of Bacteriology and Physiology, University of Edinburgh
}

SUMMARY: Pantothenic acid was essential for the growth of a strain of Lactobacillus plantarum. It increased acetylcholine formation during growth and in washed suspensions of pantothenate-deficient organisms. Added pantothenic acid did not affect the glucose utilization or lactic acid formation by the pantothenate-deficient organism in washed suspension.

The co-enzyme concerned in acetylation of choline in brain and of sulphanilamide in liver has been shown to contain pantothenic acid (Lipmann, Kaplan, Novelli, Tuttle \& Guirard, 1947). At the suggestion of Dr Lipmann, pantothenic acid was tested as a factor in the synthesis of acetylcholine by a strain of Lactobacillus plantarum. It proved to be essential both for acetylcholine formation and for growth (Stephenson \& Rowatt, 1947). This paper contains a more detailed examination of the phenomenon.

\section{Methods}

The strain, provisionally identified as $L$. plantarum, was that described by Stephenson \& Rowatt (1947), and it was maintained on media containing $1 \%$ peptone instead of the tryptic digest of casein previously used. For washed suspensions, cells were grown on Stephenson \& Rowatt's medium 5, biotin being omitted, as this had proved to have very little effect on growth. Pantothenate was not added.

Growth experiments were carried out in test-tubes each containing $10 \mathrm{ml}$. of the above medium with the inclusion of choline at a final concentration of $500 \mu \mathrm{g} . / \mathrm{ml}$. Calcium pantothenate, $\beta$-alanine, glucose, sodium acetate and cystein were sterilized by filtration. Pantoic lactone, kindly supplied by Dr F. Bergel of Roche Products Ltd., was sterilized and hydrolyzed by autoclaving in $\mathbf{0} \cdot 1 \mathrm{~N}-\mathrm{NaOH}$. When deficiencies other than that of pantothenate were investigated, the casein used was an acid hydrolysate of vitamin-free casein supplied by Ashe Laboratories. The folic acid used was a concentrate supplied by Prof. F. C. Happold. For the effect of this substance on growth, synthetic pteroylglutamic acid was substituted. All cultures were incubated at $25^{\circ}$ for $48 \mathrm{hr}$. unless otherwise stated.

Resting cells were resuspended in medium 6 of Stephenson \& Rowatt (1947). Acetate was added and the glucose concentration used was $100 \mathrm{mg} . / \mathrm{ml}$. Calcium pantothenate and other compounds were added as stated. The suspensions were incubated at $25^{\circ}$ for 3 or $4 \mathrm{hr}$.

Turbidity of suspensions and acetylcholine were estimated as previously 
described (Stephenson \& Rowatt, 1947). Glucose was estimated by the method of Miller \& van Slyke (1936) and lactic acid, after treatment with copperlime, by the method of Friedemann \& Graeser (1933).

\section{Effect of pantothenic acid on growth}

Cultures incubated for $24 \mathrm{hr}$. in a medium free from pantothenate showed no visible growth. A faint turbidity was apparent after $48 \mathrm{hr}$., but this did not increase on further incubation. In a medium containing pantothenate, growth was visible in $24 \mathrm{hr}$. and was almost complete after $48 \mathrm{hr}$.; maximal growth was obtained with $0.02 \mu \mathrm{g} . / \mathrm{ml}$. calcium pantothenate (Fig. 1).

Pantoic lactone or $\beta$-alanine $(0 \cdot 1 \mu \mathrm{g} . / \mathrm{ml}$.) did not increase growth on the pantothenate-deficient medium. If both were added together, growth was slightly greater at levels equivalent to $0 \cdot 02$, but not $0.01 \mu \mathrm{g} . / \mathrm{ml}$. calcium pantothenate (Table 1).

Table 1. Substitution of $\beta$-alanine and pantoic lactone for pantothenic acid in media for growth of Lactobacillus plantarum

\begin{tabular}{|c|c|c|c|c|c|c|c|}
\hline $\begin{array}{l}\text { Calcium pantothenate added ( } \mu \mathrm{g} \cdot / \mathrm{ml} \text {. } \\
\text { of medium) }\end{array}$ & 一 & $0 \cdot 1$ & - & - & - & - & - \\
\hline$\beta$-alanine added $(\mu \mathrm{g} . / \mathrm{ml}$. of medium $)$ & - & - & $0 \cdot 1$ & - & 0.004 & 0.008 & $0 \cdot 1$ \\
\hline $\begin{array}{l}\text { Pantoic lactone added }(\mu \mathrm{g} . / \mathrm{ml} \text {. of } \\
\text { medium) }\end{array}$ & - & - & - & $0 \cdot 1$ & $0 \cdot 006$ & $0 \cdot 012$ & $0 \cdot 1$ \\
\hline $\begin{array}{l}\text { Dry weight of cells produced (mg./ml. } \\
\text { of medium) }\end{array}$ & $0 \cdot 027$ & $0 \cdot 222$ & $0 \cdot 028$ & $0 \cdot 027$ & 0.030 & $0 \cdot 058$ & $0 \cdot 067$ \\
\hline $\begin{array}{l}\text { Acetylcholine formed }(\mu \mathrm{g} . / \mathrm{ml} . \text { of } \\
\text { medium) }\end{array}$ & $0 \cdot 44$ & $4 \cdot 8$ & $0 \cdot 36$ & $0 \cdot 34$ & $0 \cdot 34$ & $0 \cdot 48$ & 0.50 \\
\hline
\end{tabular}

\section{Effect of pantothenic acid on acetylcholine production during growth}

An increase in level of pantothenate in the growth medium caused an increase in the acetylcholine formed, whether this was calculated per unit volume of the medium or per unit dry weight of cells produced (Figs. 2, 3). Acetylcholine formation continued slowly for some days at pantothenate concentrations above $0.005 \mu \mathrm{g} . / \mathrm{ml}$, but at this level the acetylcholine content remained low. In the pantothenate-free medium, turbidity readings and acetylcholine values tended to be unreliable. This was especially so in the case of acetylcholine for which the values (per mg. cells) were very high, probably on account of substances present in the medium which increased the acetylcholine contraction of the rectus when present above a certain liminal concentration. At higher titres of acetylcholine, a smaller volume of medium was necessary for assay, and the liminal concentration of these substances was not reached. Pantoic lactone and $\beta$-alanine added separately again did not replace pantothenic acid and together gave only a small effect (Table 1).

Each of the growth factors present in the medium was omitted in turn. Nicotinamide was the only substance stimulating growth and, with it, acetylation of choline. Acetylcholine formation per mg. of cells was unaffected (Table 2(a)). $p$-Aminobenzoic acid and folic acid were treated together, both being left out of the medium and the effect of one in the absence of the other 


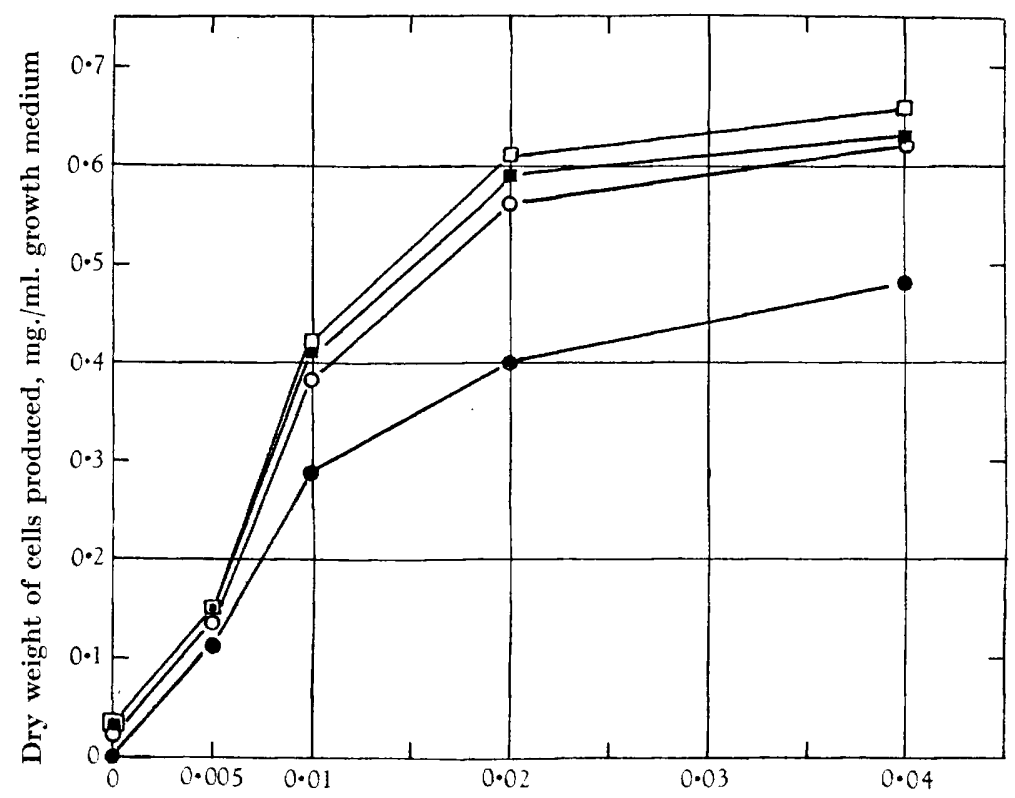

Calcium pantothenate added $(\mu \mathrm{g} . / \mathrm{ml}$. growth medium)

Fig. 1. The effect of pantothenic acid on growth of $L$. plantarum after incubation at $25^{\circ}$ for $24 \mathrm{hr}$. $-148 \mathrm{hr} . \bigcirc-\mathrm{O} ; 72 \mathrm{hr}$. $\square-\square ; 120 \mathrm{hr} . \square-\square$. Growth is not visible at $24 \mathrm{hr}$. in absence of pantothenate and cannot be measured turbidimetrically.

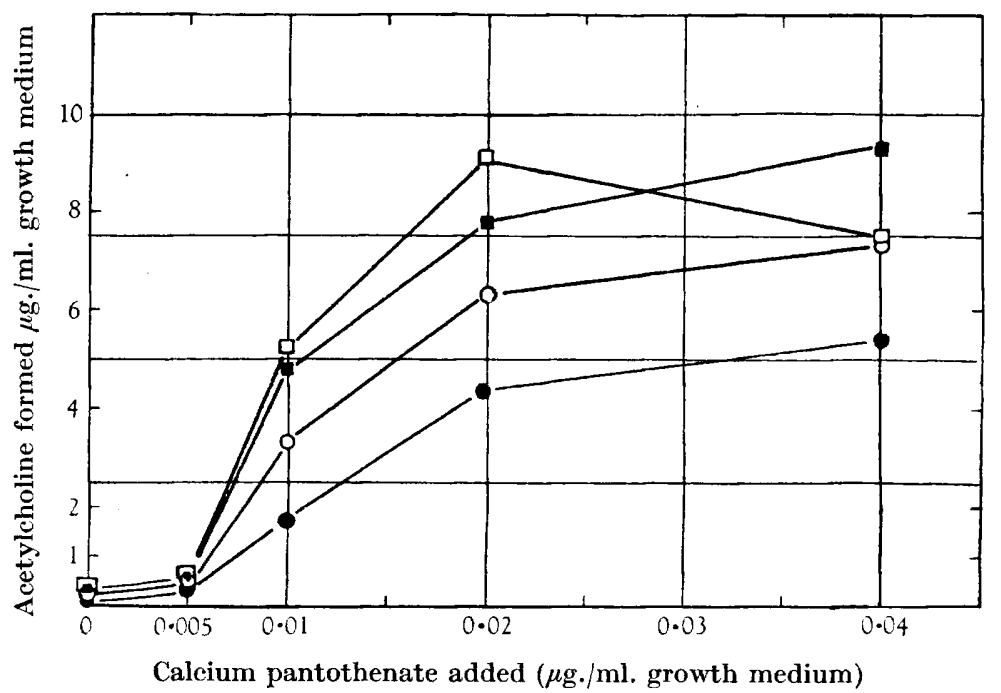

Fig. 2. The effect of pantothenic acid on acetylcholine formation per ml. of medium in growth of $L$. plantarum after incubation for $24 \mathrm{hr}$. $120 \mathrm{hr}$. $\square-\square$. 


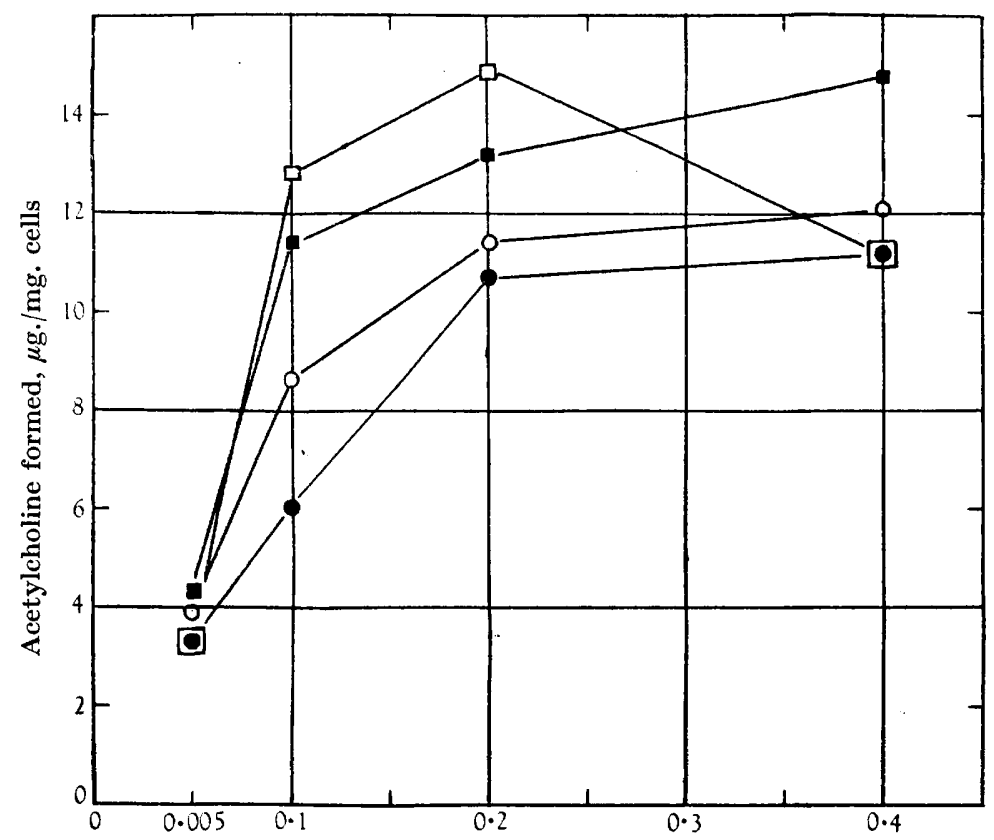

Calcium pantothenate added $(\mu \mathrm{g} . / \mathrm{ml}$. growth medium)

Fig. 3. The effect of pantothenic acid on acetylcholine formation per mg. cells in growth of L. plantarum after incubation for $24 \mathrm{hr}$. $120 \mathrm{hr} . \square-\square$.

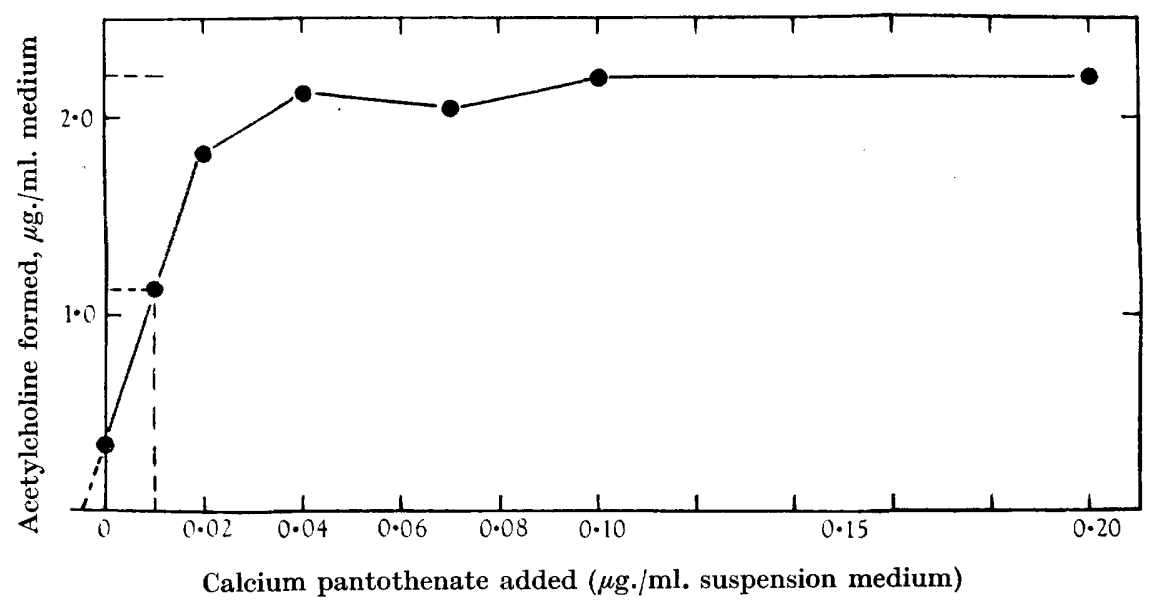

Fig. 4. The effect of pantothenic acid on acetylcholine formation by pantothenate-deficient cells of $L$. plantarum in washed suspension. The curve is produced back through the origin to cut the base, and by this means the total quantity of pantothenate in the medium is found. 


\section{Pantothenic acid and acetylcholine formation}

determined. No effect was observed on growth, but each seemed to affect acetylcholine formation (Table $2(b)$ ). Woods \& Nimmo Smith (1947) have found $p$-aminobenzoic acid to be a factor in the growth of this strain, suggesting that this substance was present in our medium. The effect of traces of growth factor carried over in inocula was not eliminated by serial subculture on the deficient media.

Table 2. Effect of nicotinamide, p-aminobenzoic acid and folic acid on growth and acetylcholine formation of Lactobacillus plantarum

(a)

Nicotinamide added $(\mu \mathrm{g} . / \mathrm{ml}$. of medium)

Dry weight of cells produced (mg./ml. of medium) $\quad 0 \cdot 185 \quad 0 \cdot 290$

Acetylcholine formed $(\mu \mathrm{g} . / \mathrm{mg}$. cells)

$25 \cdot 9 \quad 23 \cdot 1$

(b)

Pteroylglutamic acid added $(\mu \mathrm{g} . / \mathrm{ml}$. of medium $)$ $p$-Aminobenzoic acid added $(\mu \mathrm{g} . / \mathrm{ml}$. of medium) Dry weight of cells produced (mg./ml. of medium) Acetylcholine formed $(\mu \mathrm{g} . / \mathrm{mg}$. cells)

$\begin{array}{llll}0 & 0 \cdot 01 & 0 & 0 \cdot 01 \\ 0 & 0 & 0 \cdot 1 & 0 \cdot 1 \\ 0 \cdot 335 & 0 \cdot 340 & 0 \cdot 340 & 0 \cdot 335 \\ \mathbf{2 4 \cdot 8} & \mathbf{3 2 \cdot 4} & 40 & 41\end{array}$

\section{Effect of pantothenate on acetylcholine formation by pantothenate- deficient cells in washed suspension}

The crop from a litre of medium deficient in pantothenate was very small, of the order of 10-20 mg./. This contained very little acetylcholine initially, and incubation in medium 6 for $4 \mathrm{hr}$. caused an increase of as much as twice the original. With added pantothenate, a 5-6-fold increase was obtained. Under these conditions, the enzyme system became saturated with pantothenate by the addition of $0.04 \mu \mathrm{g} . / \mathrm{ml}$. calcium pantothenate to the suspension (Fig. 4). The dry weight of the cells was $0.58 \mathrm{mg} . / \mathrm{ml}$. From the curve shown in Fig. 4 it is seen that the concentration of calcium pantothenate giving $50 \%$ saturation of the enzyme system is $c .0 .014 \mu \mathrm{g} . / \mathrm{ml}$.

Addition of pantothenate to washed suspensions of cells grown in an optimal concentration of pantothenate did not increase acetylcholine formation. $\beta$-Alanine and pantoic lactone added at a level equivalent to $0 \cdot 1 \mathrm{mg} / \mathrm{ml}$. calcium pantothenate did not increase acetylcholine formation by pantothenate-deficient cells in washed suspension.

Although the addition of pantothenate to deficient suspensions increases acetylcholine formation, it had no effect on glucose utilization or lactic acid formation. For example, the glucose concentration of the suspending medium was reduced to $1.5 \mathrm{mg} . / \mathrm{ml}$., and the suspension, containing $0.66 \mathrm{mg} . / \mathrm{ml}$. cells, was incubated for $3 \mathrm{hr}$. Acetylcholine, glucose and lactic acid were estimated before and after incubation. In absence of added pantothenate, utilization of $510 \mu \mathrm{g}$. glucose gave rise to $394 \mu \mathrm{g}$. lactic acid, while $0.03 \mu \mathrm{g}$. acetylcholine was formed. When pantothenate was added, $490 \mu \mathrm{g}$. glucose was fermented to give $392 \mu \mathrm{g}$. lactic acid with the formation of $1.6 \mu \mathrm{g}$. acetylcholine. The percentage of lactic acid formed from glucose by normal suspensions of this organism is of the same order (Stephenson \& Rowatt, 1947). 
The author wishes to express her grateful thanks to Dr M. Stephenson for all her help; to Profs. T. J. Mackie and I de Burgh Daly for accommodation during the pursuance of this work; to Dr P. Eggleton for voluntary supervision; and to Miss C. Hebb and Dr E. F. Gale for help and advice. She is indebted to the Medical Research Council for a personal grant.

\section{'REFERENCES}

Friedemann, T. E. \& Graeser, J. B. (1933). The determination of lactic acid. J. biol. Chem. 100, 291.

Lipmann, F., Kaplan, N. O., Novelli, G. D., Tutrte, L. C. \& Guirard, B. M. (1947). Coenzyme for acetylation, a pantothenic acid derivative. J. biol. Chem. $167,869$.

Miller, B. J. \& van Slyke, D. D. (1936). A direct microtitration method for blood sugar. J. biol. Chem. 114, 583.

Stephenson, M. \& Rowatr, E. (1947). The production of acetylcholine by a strain of Lactobacillus plantarum. J. gen. Microbiol. 1, 279.

Woods, D. D. \& Nimmo Sмiтн, R. H. (1947). $p$-Aminobenzoic acid and folic acid derivatives in relation to bacterial growth and sulphonamide action. J. gen. Microbiol. Proc. Meeting, Sept. 1947, x.

(Received 14 June 1947) 